\title{
Preception of Adolescent Women on Sex Education of Sman 12 City of Tangerang
}

\author{
${ }^{1}$ Endah Nurpratiwi, ${ }^{2}$ Fathyah Zahra Khaula, ${ }^{3}$ Lutfiana Aulia, ${ }^{4}$ Luthfi Nur Fatimah \\ Faculty of Public Health, Muhammadiyah University of Jakarta \\ K.H. Ahmad Dahlan St, Cireundeu, Ciputat, South Jakarta, 15419 \\ E-mail: endah.nuurpratiwi@gmail.com
}

\begin{abstract}
Sex is a taboo subject to discuss, as well as sex education. Some people still tend to be cynical, and also disgusted, when they hear talk about sex, it is this negative initial perception that makes them (the young women) reluctant to study sex education, so that this misunderstanding has an impact on unhealthy sexual behavior in relationships. This study aims to determine the perception of adolescent girls regarding sex education. The research used is qualitative research using participatory observational methods. statements from the four informants regarding perceptions of sex education have good responses and good knowledge, sex education needs to be nurtured from an early age according to the age limit.
\end{abstract}

Keywords: Adolescent perception, Sex education, Young women 


\section{INTRODUCTION}

Adolescence is a period in which individuals enter adulthood or also known as the transition period. At this time, adolescents show adult behavior, such as being difficult to manage. In adolescence, individuals also experience puberty, which is a period in which individuals experience biological maturity in their genitals.

So far, the word sex is taboo to be discussed, as well as education about it. The expression of ordinary people about it will tend to be cynical, even disgusted, when they hear talk about sex, it is this negative initial perception that makes them (the young women) reluctant to study sex education, so that this misunderstanding has an impact on unhealthy sexual behavior in relationships.

Premarital sexual behavior is all behavior that is driven by sexual desire, whether done alone, with the opposite sex or same-sex without any religious ties to marriage (Sarwono, 2003). (Ahiyanasari and Nurmala, 2017)). Free sex or in a popular language called extra-marital intercourse or kinky-sex is a form of sexual liberation that is considered unnatural (Susanti, 2013 in(Rahadi and Indarjo, 2017)).

The forms of sexual behavior that are usually carried out are (1) kissing or kissing (2) necking or kissing the area around the partner's neck (3) petting or heavy sexual physical contact but not including intercourse, be it light petting (touching the partner's breasts and genitals) ) or hard petting (rubbing one's genitals to the partner's genitals, dressed or naked), and (4) intercourse or penetration of the male genitalia into the female genitalia (Susanti, 2013 in (Rahadi and Indarjo, 2017)).

According to the World Health Organization (2016), it is stated that around 21 million adolescent girls aged 15-19 years in developing countries experience pregnancy every year and almost half of these pregnancies (49\%) are unwanted pregnancies. One of these pregnancies is the cause of sexual behavior deviations which tend to increase every year(Ahiyanasari and Nurmala, 2017).

The results of a 2018 Department of Health \& Human Services survey of high school students in the United States found data on $41 \%$ of students who had had sexual intercourse, and nearly 230,000 babies were born to teenage girls aged 15-19 years. BKKBN data in 2017 found that 3.2 million teenagers 15-19 years old had unsafe abortions. Data from the Indonesian Child Protection Commission (KPAI) (2016) found that the number of child victims of abortion was 54 cases. Based on data from the $2013 \mathrm{BKKBN}$, it was found that the number of teenagers who died due to pregnancy and birth was 70,000 people. The population according to the age group of 15-24 years in Indonesia according to the results of the 2015 Inter-Census Population Survey reached 42,061.2 million or $16.5 \%$ of the total population. Data according to the Central Statistics Agency (BPS)(Ningsih, Sri and Huda, 2018).

The 2012 Indonesian Health Demographic Survey (IDHS) shows that 48 out of 1000 pregnancies in urban areas are adolescents aged 15-19 years. This figure is an increase compared to 
the 2007 IDHS findings that only 35 out of 1,000 pregnancies. Increased teenage pregnancy, one of the contributing factors is free sex behavior(Rahmawati and Devy, 2016).

The existence of deviant behavior in adolescents is caused by technological advances and the ease of accessing the internet so that children easily get the information they want to know. As a result, teenagers get sexual information earlier than previous generations.

For teenagers to avoid the negative effects of technological advances, parental control should be needed. Parents are very important to build openness with their children but this is not something easy. Children rarely want to talk about what they experience and do outside their homes. Lack of openness, and closeness, and good communication between children and parents make parents unable to know what they are doing and doing.

Communication is intended to foster good social relations. To neutralize the lack of openness, closeness, and communication, education is needed by educators or parents to explain to teenagers things related to sex, so that they do not commit or commit sexual deviations.

Sex education is an effective way to prevent teenagers from abusing sex. However, some parents still consider sex education to be a taboo subject and something that does not need to be told, they think that children will know this as they get older and they are married. This is accompanied by a lack of education and counseling carried out, and also a lack of interest in visiting places when counseling is carried out.

The condition of today's teenagers who are increasingly concerned is the impact of mistakes in understanding the meaning of sex education. The more they perceive sex as a negative thing, the more they become curious about it. Starting as a habit, eventually, become addicted. Based on the above background, the authors are interested in researching with the title "Perception of Young Women Regarding Sex Education in Larangan Selatan Village, Tangerang City in 2021"

\section{METHODS}

The type of research used is qualitative research using participatory observational methods, where this research is carried out by interviewing respondents in-depth (in-depth interviews) which in general is a process of obtaining information for research purposes using question and answer while face to face or through communication media. between interviewers and informants, with or without using interview guidelines. Interviews conducted by researchers lasted approximately 20-30 minutes. 


\section{RESULTS AND DISCUSSION}

Table 1. Interview Results

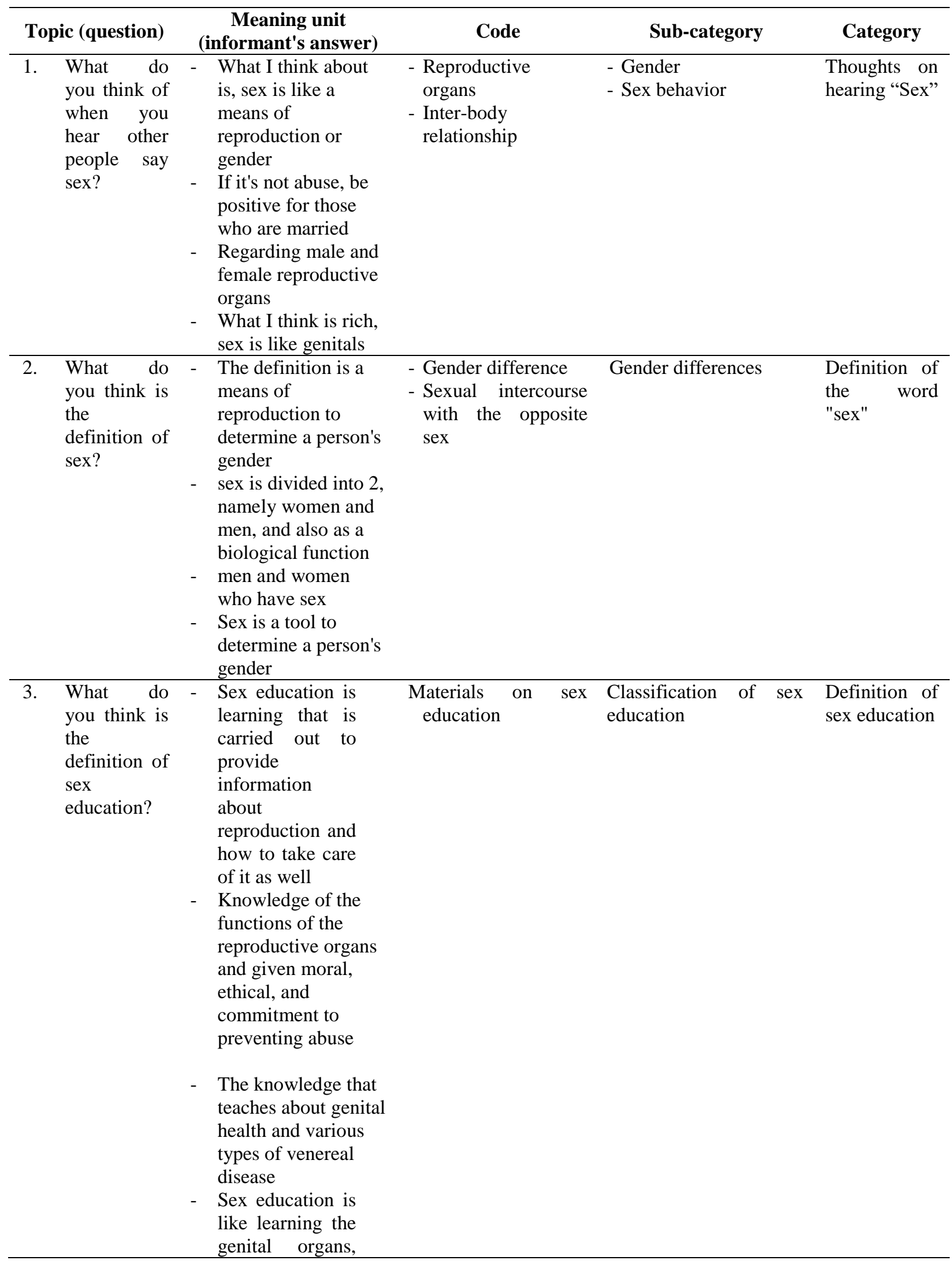




\begin{tabular}{|c|c|c|c|c|}
\hline Topic (question) & \multirow{2}{*}{$\begin{array}{l}\text { Meaning unit } \\
\text { (informant's answer) } \\
\text { how to treat } \\
\text { them, venereal } \\
\text { diseases, such as } \\
\text { reproductive } \\
\text { health that occur } \\
\text { in both men and } \\
\text { women. }\end{array}$} & Code & \multirow[t]{2}{*}{ Sub-category } & \multirow[t]{2}{*}{ Category } \\
\hline & & & & \\
\hline $\begin{array}{l}\text { 4. What do } \\
\text { you think is } \\
\text { the purpose } \\
\text { of sex } \\
\text { education? }\end{array}$ & $\begin{array}{l}\text { - I think it's to teach } \\
\text { lessons, like how to } \\
\text { take care of } \\
\text { reproductive parts or } \\
\text { tools, what can be } \\
\text { done and what can't } \\
\text { be done. } \\
\text { - } \text { to minimize sexual } \\
\text { violence, and get } \\
\text { pregnant out of } \\
\text { wedlock } \\
\text { To understand the } \\
\text { importance of taking } \\
\text { care of yourself } \\
\text { from disease } \\
\text { The purpose of sex } \\
\text { education is very } \\
\text { good because it can } \\
\text { avoid venereal } \\
\text { disease if for } \\
\text { example we already } \\
\text { know how to take } \\
\text { care of it so be more } \\
\text { careful }\end{array}$ & \begin{tabular}{lr} 
- & \multicolumn{3}{c}{ How to care for and } \\
maintain & vital \\
organs & \\
- Reduce & sexual \\
violence &
\end{tabular} & $\begin{array}{l}\text { Information and } \\
\text { knowledge }\end{array}$ & $\begin{array}{l}\text { The purpose } \\
\text { of sex } \\
\text { education }\end{array}$ \\
\hline $\begin{array}{l}\text { 5. What do } \\
\text { you think } \\
\text { are included } \\
\text { in sexual } \\
\text { behavior? }\end{array}$ & $\begin{array}{l}\text { - Hmm, rich in } \\
\text { hanging out with the } \\
\text { opposite sex, then } \\
\text { rich in fantasizing } \\
\text { about pornographic } \\
\text { things and watching } \\
\text { porn. } \\
\text { - Any behavior that is } \\
\text { driven by sexual } \\
\text { desire, both with the } \\
\text { opposite sex and } \\
\text { with the same sex, } \\
\text { watching porn and } \\
\text { having sex before } \\
\text { marriage } \\
\text { harassment in public } \\
\text { places such as } \\
\text { teasing the opposite } \\
\text { sex by whistling, or } \\
\text { touching others } \\
\text { without permission } \\
\text { The form of sexual } \\
\text { behavior is like } \\
\text { dating in a western } \\
\text { style, for example }\end{array}$ & Doing sexual activity & $\begin{array}{l}\text { - Activity } \\
\text { - various kinds of } \\
\text { sexual behavior }\end{array}$ & Sex activity \\
\hline
\end{tabular}




\begin{tabular}{|c|c|c|c|c|}
\hline Topic (question) & \multirow{2}{*}{$\begin{array}{c}\begin{array}{c}\text { Meaning unit } \\
\text { (informant's answer) }\end{array} \\
\text { kissing or more than } \\
\text { that having sex }\end{array}$} & \multirow[t]{2}{*}{ Code } & \multirow[t]{2}{*}{ Sub-category } & \multirow[t]{2}{*}{ Category } \\
\hline & & & & \\
\hline $\begin{array}{l}\text { 6. In your } \\
\text { opinion, } \\
\text { what causes } \\
\text { teenagers to } \\
\text { have free } \\
\text { sex? }\end{array}$ & $\begin{array}{l}\text { - I think it's because } \\
\text { they lack sex } \\
\text { education } \\
\text { Pendidikan } \\
\text { - starting from } \\
\text { curiosity and } \\
\text { hormones that are } \\
\text { peaking in } \\
\text { adolescence } \\
\text { Free association, } \\
\text { lack of knowledge } \\
\text { about the } \\
\text { consequences, } \\
\text { following the } \\
\text { association of } \\
\text { friends } \\
\text { In my opinion, those } \\
\text { who do free sex can } \\
\text { be due to lack of } \\
\text { attention from } \\
\text { parents and don't } \\
\text { know the risks of } \\
\text { free sex }\end{array}$ & $\begin{array}{l}\text { - Teen knowledge } \\
\text { - Occurs because of } \\
\text { biological things } \\
\text { - Lack of love }\end{array}$ & $\begin{array}{l}\text { - Lack of knowledge } \\
\text { about sex } \\
\text { - Biological } \\
\text { - Feeling ignored }\end{array}$ & $\begin{array}{l}\text { Cause free } \\
\text { sex }\end{array}$ \\
\hline $\begin{array}{l}\text { 7. In your } \\
\text { opinion, } \\
\text { who can } \\
\text { plunge } \\
\text { teenagers } \\
\text { into free sex } \\
\text { behavior? }\end{array}$ & $\begin{array}{l}\text { - The average is from } \\
\text { the association of } \\
\text { friends, yes, it's the } \\
\text { same at first, try it, it } \\
\text { just goes on and on } \\
\text { - friends around, } \\
\text { wrong association } \\
\text { greatly affects } \\
\text { - From friends } \\
\text { - The most annoying } \\
\text { thing is usually the } \\
\text { association of } \\
\text { friends, brother }\end{array}$ & $\begin{array}{l}\text { - association } \\
\text { - Role models } \\
\text { - Environment }\end{array}$ & $\begin{array}{l}\text { Influenced by friends } \\
\text { and surroundings }\end{array}$ & $\begin{array}{l}\text { Teenagers } \\
\text { fall into free } \\
\text { sex }\end{array}$ \\
\hline $\begin{array}{l}\text { 8. What } r \\
\text { you } \\
\text { about } \\
\text { sex? }\end{array}$ & $\begin{array}{l}\text { - I think it's dangerous } \\
\text { for sure, because } \\
\text { there are many risks } \\
\text { from free sex like } \\
\text { there are diseases, } \\
\text { you can get pregnant } \\
\text { too } \\
\text { - In my opinion, sex } \\
\text { has become a } \\
\text { common thing in the } \\
\text { discussion, what else } \\
\text { on the internet, some } \\
\text { so many teenagers } \\
\text { tell their experiences } \\
\text { about free sex } \\
\text { It is a common thing } \\
\text { that is often done } \\
\text { and is hidden from }\end{array}$ & $\begin{array}{l}\text { - Disease Pregnant } \\
\text { - It's normal } \\
\text { - The impact of free } \\
\text { sex }\end{array}$ & $\begin{array}{l}\text { Sexual behavior that } \\
\text { risks getting sick and } \\
\text { getting pregnant out of } \\
\text { wedlock }\end{array}$ & $\begin{array}{l}\text { Views about } \\
\text { free sex }\end{array}$ \\
\hline
\end{tabular}




\begin{tabular}{|c|c|c|c|c|}
\hline Topic (question) & $\begin{array}{c}\text { Meaning unit } \\
\text { (informant's answer) }\end{array}$ & Code & Sub-category & Category \\
\hline & $\begin{array}{l}\text { parents } \\
\text { Of course, it's } \\
\text { dangerous, Sis, } \\
\text { because if you have } \\
\text { free sex you can get } \\
\text { pregnant and it can } \\
\text { make you sick with } \\
\text { genital infections }\end{array}$ & & & \\
\hline $\begin{array}{l}\text { 9. In your } \\
\text { opinion, } \\
\text { what are the } \\
\text { factors that } \\
\text { cause } \\
\text { damage to } \\
\text { the minds of } \\
\text { teenagers? }\end{array}$ & $\begin{array}{l}\text { Factors from social } \\
\text { media, the internet } \\
\text { which is now very } \\
\text { easy to access, as } \\
\text { well as things that } \\
\text { smell like porn } \\
\text { - } \text { too often watch the } \\
\text { internet without } \\
\text { parental supervision } \\
\text { - Irresponsible web, } \\
\text { watching movies } \\
\text { with vulgar scenes } \\
\text { on the big screen } \\
\text { Because of social } \\
\text { media, bro, do you } \\
\text { watch porn videos } \\
\text { and ban movies that } \\
\text { you can't watch but } \\
\text { can still watch }\end{array}$ & $\begin{array}{l}\text { Social media and the } \\
\text { internet in }\end{array}$ & $\begin{array}{l}\text { Influenced by the } \\
\text { internet and social } \\
\text { media }\end{array}$ & $\begin{array}{l}\text { Causes of } \\
\text { damage to the } \\
\text { teenage mind }\end{array}$ \\
\hline $\begin{array}{l}\text { 10. Why do you } \\
\text { think so } \\
\text { many teens } \\
\text { have sex but } \\
\text { don't get } \\
\text { pregnant? }\end{array}$ & $\begin{array}{l}\text { - I guess it's because } \\
\text { they already know } \\
\text { about sex education, } \\
\text { how to prevent it by } \\
\text { using contraceptives } \\
\text { many teenagers who } \\
\text { may have received } \\
\text { sex education and } \\
\text { misuse this } \\
\text { knowledge, for } \\
\text { example, the use of } \\
\text { condoms is done by } \\
\text { many teenagers who } \\
\text { are not legal } \\
\text { Teenagers today are } \\
\text { smart, smart, of } \\
\text { course, they have } \\
\text { looked for ways } \\
\text { from the internet } \\
\text { how to prevent } \\
\text { pregnancy and how } \\
\text { to prevent it, they } \\
\text { can use condoms } \\
\text { because condoms } \\
\text { are already popular } \\
\text { among us compared } \\
\text { to other safeguards. } \\
\text { Usually, it's like } \\
\text { that, they have sex }\end{array}$ & $\begin{array}{l}\text { - Educational sex } \\
\text { - Types of } \\
\text { contraceptives }\end{array}$ & $\begin{array}{l}\text { Understanding the use } \\
\text { of contraceptives }\end{array}$ & Outcome \\
\hline
\end{tabular}




\begin{tabular}{|c|c|c|c|c|}
\hline Topic (question) & $\begin{array}{c}\text { Meaning unit } \\
\text { (informant's answer) }\end{array}$ & Code & Sub-category & Category \\
\hline & $\begin{array}{l}\text { using a condom, you } \\
\text { know that you } \\
\text { already know about } \\
\text { sex knowledge }\end{array}$ & & & \\
\hline $\begin{array}{l}\text { 11. What do } \\
\text { you think is } \\
\text { the right } \\
\text { method to } \\
\text { deliver sex } \\
\text { education to } \\
\text { teenagers }\end{array}$ & $\begin{array}{l}\text { The most effective } \\
\text { way is by telling the } \\
\text { impact or risk of the } \\
\text { risk as well as } \\
\text { telling the disease } \\
\text { too } \\
\text { more often do } \\
\text { seminars or other } \\
\text { things about sex } \\
\text { education because } \\
\text { many teenagers may } \\
\text { already know but } \\
\text { forget. } \\
\text { Usually using media } \\
\text { that is easy for } \\
\text { children my age to } \\
\text { understand, for } \\
\text { example, videos } \\
\text { about sex education, } \\
\text { the risk is the same } \\
\text { and the } \\
\text { consequences are } \\
\text { more fearful so that } \\
\text { teenagers are far } \\
\text { away from sexual } \\
\text { behavior } \\
\text { Usually, teenagers } \\
\text { are like my age, they } \\
\text { can listen if you } \\
\text { explain it like using } \\
\text { a video or an } \\
\text { illustration of the } \\
\text { risks, if that's the } \\
\text { case they are usually } \\
\text { afraid } \\
\end{array}$ & $\begin{array}{l}\text { - Impact and Risk } \\
\text { - Learning }\end{array}$ & $\begin{array}{l}\text { Understanding of sex } \\
\text { education }\end{array}$ & method \\
\hline 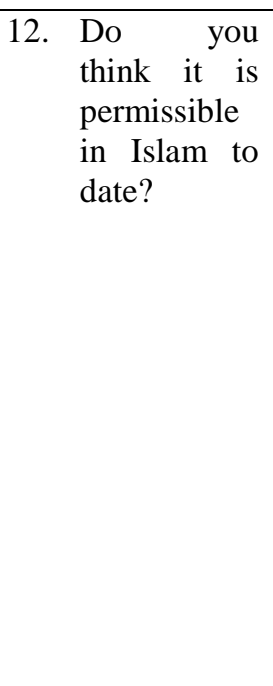 & $\begin{array}{l}\text { - It's not okay, } \\
\text { because in religion, } \\
\text { especially in Islam, } \\
\text { dating is the entry of } \\
\text { adultery, a big sin, } \\
\text { so you can't date } \\
\text { - In the verses and } \\
\text { hadiths that I know, } \\
\text { it is not permissible } \\
\text { for those who are } \\
\text { not makhram to } \\
\text { touch let alone } \\
\text { commit adultery, } \\
\text { therefore dating is } \\
\text { not allowed because } \\
\text { of adultery. } \\
\text { I don't think it's okay }\end{array}$ & Adultery & Bad attitude & $\begin{array}{l}\text { Religious } \\
\text { teachings }\end{array}$ \\
\hline
\end{tabular}




\begin{tabular}{|c|c|c|c|c|}
\hline Topic (question) & $\begin{array}{c}\text { Meaning unit } \\
\text { (informant's answer) }\end{array}$ & Code & Sub-category & Category \\
\hline & $\begin{array}{l}\text { because there is a } \\
\text { verse in the Qur'an } \\
\text { that forbids being } \\
\text { close to someone } \\
\text { who is not a muhrim } \\
\text { - I don't think it's } \\
\text { allowed, Sis, I've } \\
\text { heard lectures that } \\
\text { said don't approach } \\
\text { adultery, so if we're } \\
\text { dating, we'll } \\
\text { approach adultery. }\end{array}$ & & & \\
\hline 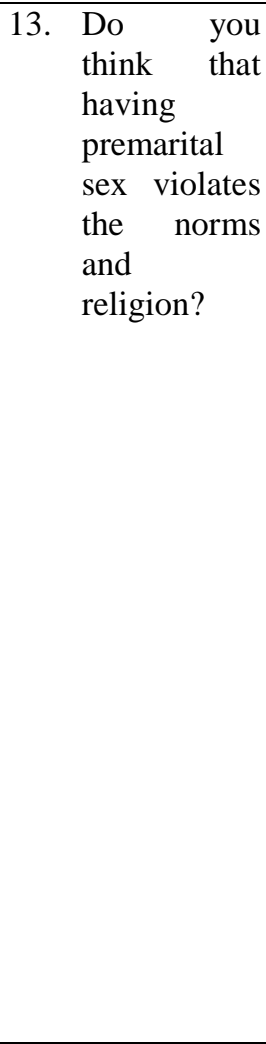 & $\begin{array}{l}\text { - Of course, it violates } \\
\text { norms and religion, } \\
\text { because having sex } \\
\text { before it's halal } \\
\text { - Just dating is } \\
\text { adultery, especially } \\
\text { premarital sex which } \\
\text { violates religious } \\
\text { norms and is very } \\
\text { unethical and should } \\
\text { be avoided from } \\
\text { such behavior. } \\
\text { Yes, it's a violation, } \\
\text { because it's clear } \\
\text { that sex before } \\
\text { marriage destroys } \\
\text { the minds of } \\
\text { teenagers in is } \\
\text { This is a violation } \\
\text { because the majority } \\
\text { of Indonesia is } \\
\text { Muslim, sex is } \\
\text { premarital sex } \\
\text { prohibited from } \\
\text { religion and norms } \\
\text { in our country. }\end{array}$ & $\begin{array}{l}\text { - A religious norm } \\
\text { - Social norms }\end{array}$ & $\begin{array}{ll}\text { - Violating religious } \\
\text { norms }\end{array}$ & $\begin{array}{l}\text { Religious } \\
\text { teachings }\end{array}$ \\
\hline
\end{tabular}

The results of this study indicate the perception of adolescents about sex education. Where sex education is seen by teenagers as something important, positive value, and useful for them in helping the problems of adolescent life. Through sex education, adolescents can direct their sexual behavior so that they do not deviate from existing norms and can avoid negative things. In other words, adolescents view sex education as a tool to prevent sexual abuse. Teenagers consider sex education to be able to answer their curiosity and curiosity about all things related to sex. Therefore, teenagers consider sex education as a necessity and they do not taboo.

Teenagers' view of sex itself is not much different from the view of society in general. From the results of the interviews, several informants gave similar arguments, most of them said that when they heard the word sex, their minds usually focused on gender. 
The following is an excerpt from an in-depth interview obtained:

"What I think about is that sex is like a means of reproduction or gender", "If it's not lawful, including abuse, it becomes positive for those who are married", "In my opinion, sex is about male and female reproductive organs".

From some of the opinions above, it can be concluded that the perception of young women regarding sex education is gender.

Sex education is seen as being able to provide a correct understanding of sex. Sex education is an effort that seeks to equip someone with knowledge about sex. The goal is to make someone understand sex so that they can put sex in a good and right perspective and change wrong and negative perceptions about sex. Another purpose of sex education is to be able to direct individuals to behave positively and avoid sexual abuse.

The following is an excerpt from an in-depth interview obtained:

"Sex education is learning that is carried out to provide information about reproduction and how to take care of it, besides that sex education is to provide lessons, such as how to take care of reproductive parts or tools, what can be done, and what can't be done.", "Knowledge about the functions of reproductive organs and given moral morals, ethics and commitment to prevent abuse and to minimize sexual violence, and pregnancy out of wedlock", "Knowledge that teaches about genital health and various kinds of venereal disease".

From some of the opinions above, it can be concluded that the meaning of sex education is a medium of information about reproductive organs, how to take care of genital hygiene, being informed about sexually transmitted diseases, then about morals and ethics.

In the perspective of Islam, it is very serious in addressing behavioral problems

sexuality or better known as behavior approaching adultery. Among the laws regarding sexual behavior in Islam is the prohibition of a woman intentionally showing her beauty in front of men who are not married, wearing tight and transparent clothing, and wearing perfume with a striking fragrance. At the same time, men are not allowed to look at women with lust

The following is an excerpt from an in-depth interview obtained:

"In religion, it is not allowed to do things like adultery, because it will cause a big sin", "In the verses and hadiths that I know it is not allowed to touch each other, let alone commit adultery", "In the verse of the Koran it is explained that it is not permissible to approach adultery ", "Have you ever come to a lecture venue if you do something that is adulterous, it is strictly forbidden by Allah SWT."

From some of the opinions above, it can be concluded that based on the perspective of Islam, contact with the opposite sex is prohibited because it can get closer to the behavior of the big sin, namely adultery. 
Perception is a person's activity in assessing and understanding objects around him by using the senses he has so that what has been understood through these senses they can give a positive response.

This statement is in line with research conducted by (Finkelhor 2009 in Anggraini trinita, et al 2017) which states that the purpose of efforts to prevent sexual abuse of children in the field of education (sex education) is so that children can identify dangerous situations and prevent sexual harassment. and teach children the forms of bad touch, how to refuse or end interactions with my palaku or suspicious people, and how to ask for help.

Sex education is a knowledge that we teach about everything related to gender, ranging from sex growth (male or female), sex function as a means of reproduction, menstruation, wet dreams, etc.

This statement is in line with research conducted by (SEF 2011 in Risty Justica 2017) which suggests that early childhood sex education is not only about anatomical differences between men and women or the development of reproductive organs but also equips children with self-confidence, increasing children's competence and developing attitudes so that they are expected to be protected from sexual harassment and infectious diseases such as HIV and AIDS.

In the perspective of Islam, learning is an obligation for every believer to acquire knowledge to improve the degree of their lives.

This statement is in line with the opinion (Hasan Hathiut 1994 in Sakutra, Muhammad Indra 2016) which states that facts about sex must be taught to adolescents in a way according to their age growth, both by family and school. We emphasize that this must be done in the context of Islamic ideology and the comprehensive teachings of Islam (kafah), so that young people, apart from obtaining the correct psychological knowledge, become fully aware of the sanctity of sexual relations in Islam and the major sin in the sight of Allah SWT.

\section{CONCLUSIONS AND SUGGESTIONS}

Adolescent perceptions of sex education have the aim of preventing sex abuse so that children can identify dangerous situations and prevent sexual harassment, as well as teach children the forms of bad touch, how to refuse or end interactions with suspicious perpetrators or people, and how they ask for help.

According to religion, sex education must be taught and given knowledge so that teenagers get the correct psychological knowledge, become fully aware of the sanctity of sexual relations in Islam and the main big sin in the sight of Allah SWT.

It is better for the role of parents in the life of the family environment to provide knowledge about sex education so that children can identify dangerous situations that could potentially lead to sexual harassment. 


\section{REFERENCES}

Ahiyanasari, CE and Nurmala, I. (2017) 'INTENTIONS OF HIGH SCHOOL STUDENTS TO PREVENT PREMARRIAGE SEX'.

Chabib, T. (1996) 'The Concept of Sex Education, (1), pp. 23-53.

Junita, S. (2018) 'The relationship of knowledge and attitudes about reproductive health with premarital sex behavior in students who take part in pik-r activities in high school districts. help 2017'.

Ningsih, P., Sri, U. and Huda, N. (2018) 'INFLUENCE OF HEALTH EDUCATION METHODS OF THE REDI PLAY (EDUCATION AND INSPIRATION WHEEL) ON KNOWLEDGE OF ADOLESCENT WOMEN TO PREVENT SEX', pp. 563-571.

Rahadi, DS and Indarjo, S. (2017) 'FREE SEX BEHAVIOR IN MOTOR X CLUB MEMBERS IN SEMARANG CITY IN 2017', 2(2), pp. 115-121.

Rahmawati, CD and Devy, SR (2016) 'SOCIAL SUPPORT THAT ENCOURAGES PREMARRIAGE SEX BEHAVIOR IN ADOLESCENT SMA $X$ IN THE CITY OF SURABAYA', pp. 129-139.

Rosyida, D. (2019) Textbook of Adolescents and Women's REPRODUCTIVE HEALTH. Yogyakarta: PT. NEW LIBRARY.

Setiawati, D. (2010) 'Adolescents' PERCEPTIONS OF SEX EDUCATION.

Untari, ADWI (2017) 'analysis of factors related to premarital sexual behavior in adolescents living in ex-localization areas based on theory'. 